\title{
KIK A NYERTESEI AZ ISKOLAI KÖZÖSSÉGI SZOLGÁLATNAK? - AZ ISKOLAI KÖZÖSSÉGI SZOLGÁLAT IRÁNTI POZITÍV ATTITŰDÖKET BEFOLYÁSOLÓ TÉNYEZŐK VIZSGÁLATA
}

MARKOS VALÉRIA ${ }^{1}$

DOI: https://doi.org/10.53585/OnkSzem.2021.1.69-82

\section{Absztrakt}

Magyarországon 2012-ben vezették be az iskolai közösségi szolgálatot, melynek egyik legfőbb célja a fiatalok önkéntességre való motiválása. Az iskolai közösségi szolgálat hosszabb távú hatását az elkövetkezendő években lehet majd vizsgálni, jelenleg az első tapasztalatokat tudjuk kimutatni. Jelen tanulmányunk elsődleges célja annak bemutatása, hogy milyen tényezők befolyásolják a szolgálat iránti pozitív attitűdök kialakulását, és milyen szociokulturális tényezőkkel jellemezhetők azok a tanulók, akik szívesen végezték a szolgálatot és pozitívan emlékeznek vissza az ötven órára. A nemzetközi irodalomból ismert service-learning (közösségi szolgálat) tantárgyak pozitív hatásainak bemutatásán túl ismertetjük a hazai iskolai közösségi szolgálatot. 2019-ben folytatott nagymintás keresztmetszeti vizsgálatunk néhány eredményét közöljük, melynek kapcsán választ kapunk arra, hogy milyen tényezők segítik a pozitív attitűdök kialakulását, és kik azok a tanulók, akik pozitív attitűdöket társítanak a szolgálathoz. Végül megfogalmazzuk javaslatainkat, amelyek segítséget nyújthatnak az iskolai közösségi szolgálat fejlesztéséhez és a Nemzeti Önkéntes Stratégia 2021-2030 kialakításához.

Kulcsszavak: iskolai közösségi szolgálat, önkéntesség, pozitív attitűdök

Who are the winners of the school community service? - Investigation of factors affecting positive attitudes towards school community service

\section{Valéria Markos}

\section{Abstract}

In Hungary, the school community-service was introduced in 2012, with the main aim of motivating young people to volunteer. The longer-term effect of school community-service will be investigated in the following years, now we can study the first experiences. The primary aim of our present study is to show what factors influence the development of positive attitudes toward service and what sociocultural factors characterize students who enjoyed service and remember fifty hours positively. In addition to presenting the positive effects of service-learning subjects known from the international literature, we describe the Hungarian school community service. We present some of the results from our large-sample cross-sectional study conducted in 2019, which provides an answer to the question of what factors contribute to the development of positive attitudes and who are the students who

\footnotetext{
${ }^{1}$ Markos Valéria (PhD) szociológus, kutató-elemző, Kopp Mária Intézet a Népesedésért és a Családokért
} 
associate positive attitudes with service. Finally, we formulate our proposals that can contribute to the development of the school community-service and National Voluntary Strategy 2021-2030.

Keywords: school community-service, service learning, volunteering, positive attitudes

\section{BEVEZETÉS}

A 2012-ben megalkotott Nemzeti Önkéntes Stratégia (2012-2020) legfőbb célja, hogy felhívja a figyelmet a társadalmi felelősségvállalás és az önkéntesség fontosságára, amelynek egyéni és társadalmi szinten is kedvező hatásai vannak. A dokumentum 2020-ig olyan célokat és prioritásokat jelölt ki, mely a különböző társadalmi csoportok körében az önkéntesek számának növekedését célozza meg.

A Nemzeti Önkéntes Stratégia (2012-2020) egy időben született az iskolai közösségi szolgálat bevezetésével, így a dokumentum még kevésbé számolhatott az iskolai közösségi szolgálat pozitív hatásaival. Elsősorban elhatárolódik tőle, mivel kötelezősége negatívan hathat az önkéntesség tartalmára. Kiemelt célként kezeli a fiatalok önkéntességbe való bevonását, elsősorban a 18-26 éven felüli fiatalok önkéntességben való részvételében számít pozitív elmozdulásra.

Véleményünk szerint fontos, hogy az önkéntességbe való bevonódás szocializációs folyamattá váljon, mely már gyermekkorban kezdetét veszi, és az élethosszig tartó önkéntesség képét vetíti előre. Az oktatáskutatás területén évtizedek óta központi kérdés, hogy az oktatási rendszer hogyan képes ehhez hozzájárulni, és hogyan segítheti a társadalmi részvétel növelését, az aktívabb állampolgári szerepvállalást és a társadalmi szolidaritás erősítését (Jones - Kiser 2014; Clifford 2017). Az Amerikai Egyesült Államokban megjelent servicelearning (szolgálati tanulás) jó példával szolgált ahhoz, hogy az ezredfordulót követően több európai ország oktatási rendszerében is megjelentek hasonló jellegű, tapasztalati tanuláson alapuló, szolgálati jellegű programok (Bekkers 2009; Vonk 2011; Dokter 2011; Baltes - Seifert 2010; Zentner 2011).

A Magyarországon bevezetett iskolai közösségi szolgálat, bár tartalmában jelentősen eltér a nemzetközi gyakorlatban igazolt service-learning jellegű programoktól, mégis nagymértékben hozzájárult az önkéntességi mutatók pozitív elmozdulásához. 
Tanulmányunkban az iskolai közösségi szolgálattal kapcsolatos átfogó kutatási eredményeinket közöljük, mely során a középiskolás tanulók iskolai közösségi szolgálattal kapcsolatos tapasztalatait vizsgáltuk. A kutatás elsődleges célja annak vizsgálata volt, hogy feltárjuk, melyek azok a tényezők, amelyek segíthetik az iskolai közösségi szolgálat céljainak elérését, és ami támogathatja a szolgálat iránti pozitívabb attitűdök kialakulását, ezáltal motiválhatja a fiatalokat a későbbi önkéntes tevékenységvégzésre.

\section{A SERVICE-LEARNING JELLEGŰ PROGRAMOK POZITÍV HATÁSAI}

A nemzetközi szakirodalomból ismert service learning és community service fogalmak állnak legközelebb a magyarországi iskolai közösségi szolgálat gyakorlatához. A service learning és a community service közötti különbség Furco (1996) szerint abban nyilvánul meg, hogy míg a service-learning elsősorban a tanulásra, a community service inkább a szolgálatra helyezi a hangsúlyt. Mindkettőben közös, hogy a tapasztalati tanulás által támogatja az állampolgári felelősség kialakulását, így az oktatási rendszer biztosítani tudja azt a formális keretet, amelyen belül végbemehet a tanulók állampolgári nevelése.

A service learning azont túl, hogy kedvező hatással van a jövőbeli önkéntességi mutatókra, pozitív kompetenciafejlesztő hatásai is ismertek. Egyrészt javul a diákok tanulmányi eredményessége, nagyobbak a tanulási aspirációik, több időt fordítanak tanulásra, szakmailag fejlődnek, fejlődik a tanulási önkép, javul a matematikai- és íráskészség és az intellektuális önbizalom. A service learning-et végzettek többen vállalnak extracurriculáris, tanórán kívüli tevékenységet, és szorosabb a tanárokkal való kapcsolatuk. A program hatására az egyén és az intézmény kapcsolata erősödik, nő az elégedettség az intézménnyel szemben és nagyobb arányban történik sikeres végzés is.

Másrészt a service learning fejleszti az életben való boldoguláshoz szükséges készségeket és kompetenciákat is, pl. a vezetői ambíciókat és képességeket, a szociális önbizalmat, a kritikai gondolkodást, a problémamegoldó készségeket, az interperszonális és kommunikációs készségeket, a konfliktusmegoldó készséget és a team munka készségeket. Emellett növelheti a más kultúrákról, etnikumokról való ismereteket, a közösséggel kapcsolatos problémák jobb megértését, elősegítheti az egyéni értékrend, célok és attitűdök változását és a nagyobb toleranciát más csoportokkal szemben. Harmadrészt a service learning fejleszti az állampolgári tudatosságot és felelősségvállalást, növelheti az általános bizalmat, a társadalmi igazságosság 
és méltányosság elfogadását és a politikai aktivitást. Végül fontos szempont a morális fejlődés és a későbbi önkéntességre való hajlam erősödése (Fényes - Markos 2016).

\section{ISKOLAI KÖZÖSSÉGI SZOLGÁLAT MAGYARORSZÁGON}

Magyarországon a 2016-os tanév óta az érettségi bizonyítvány kiadásának feltétele az iskolai közösségi szolgálat teljesítése. A középiskolás évek alatt a diákoknak ötven óra szolgálati tevékenységet kell teljesíteniük olyan szervezeteknél, melyek az oktatási intézményükkel együttmúködési megállapodásban állnak. Így az érettségi vizsga azon túl, hogy a tantárgyi tudást igazolja, felhívja a figyelmet arra is, hogy a felelős állampolgári magatartás és a szociális érzékenység fejlesztése hozzátartozik a középfokú tanulmányok lezárásához. Az iskolai közösségi szolgálatot öt óra felkészítő óra előzi meg és öt óra lezáró foglalkozás követi. Míg a felkészítés célja a közösségi szolgálat megismertetése a diákokkal és a motiváció felkeltése, addig a lezáró foglalkozásokon a tapasztalatok feldolgozása történik meg.

Ahogy már a bevezetőben említettük, az iskolai közösségi szolgálat tartalmi jellegében jelentősen eltér a nemzetközi gyakorlatban ismert service-learning és community-service jellegú programoktól (Bodó 2015a; Markos 2016), célja mégis hasonlóan az, hogy növelje a fiatalok állampolgári aktivitását, motiválja őket az önkéntességre, fejlessze a szociális érzékenységüket, segítse a pályaorientációt és a pályaszocializációt, támogassa a kapcsolati háló bővítését (Markos 2020).

Az iskolai közösségi szolgálattal kapcsolatos hazai tanulmányok több aspektusból közelítik meg a tapasztalatok feltárását. A kutatások egyrészt a pedagógusok és az intézményvezetők véleményét és tapasztalatait vizsgálják a közösségi szolgálattal kapcsolatban (Bodó 2015b; 2016), másrészt egy-egy iskola helyi programjának tapasztalatait mutatják be (Bilik 2013; Domján 2014; Velkey 2014), de a civil szervezetek koordinátorainak tapasztalatait is feltárták már empirikus úton (Markos 2018).

A kutatások a közösségi szolgálat pozitív eredményein túl rávilágítanak arra is, hogy milyen nehézségekkel néznek szembe a pedagógusok és a közösségi szolgálati koordinátorok a szolgálat megszervezése és adminisztratív teendői során, valamint a tanulók az 50 óra teljesítése alatt (Bodó 2015a; 2015b; Markos 2020). 
Mivel hazánkban a 2012-es tanévben került bevezetésre a közösségi szolgálat, jelenleg az első tapasztalatokat és attitűdöket tudjuk vizsgálni azzal kapcsolatban, hogy milyen egyéni és társadalmi hatásai vannak a szolgálatnak. A következőkben a 2019-ben végzett keresztmetszeti kutatásunk néhány főbb eredményét ismertetjük (Markos 2020).

\section{Az iskolai közösségi szolgálat tapasztalatait vizsgáló kutatás bemutatása}

Kutatásunkban a középiskolás diákok tapasztalatai alapján vizsgáltuk az iskolai közösségi szolgálat implementációjának megvalósulást. Kutatásunk újszerűsége volt, hogy nagymintás kvantitatív elemzéssel, két- valamint többváltozós statisztikai módszerekkel, és társadalmi háttérváltozók bevonásával vizsgáltuk az iskolai közösségi szolgálat céljainak megvalósulását. A keresztmetszeti vizsgálat során három kelet-magyarországi megye (Hajdú-Bihar, SzabolcsSzatmár-Bereg és Borsod-Abaúj-Zemplén megye) 12. évfolyamos középiskolás diákjai körében végeztünk kérdőíves felmérést. A kérdőívünket kitöltő diákokat többlépcsős, rétegzett, csoportos mintavételi eljárás segítségével választottuk ki. Gondot fordítottunk arra, hogy alacsony, közepes és magas önkéntességi rátával rendelkező megyékre essen a választás, majd az Oktatási Hivatal Köznevelési Információs Rendszerének adatbázis segítségével valószínúségi alapon, szisztematikus mintavétellel több lépcsőben választottuk ki a megkérdezett tanulókat. Összesen 637 fiatal töltötte ki a kérdőívünket.

\section{A pozitív attitüdöket befolyásoló tényezők}

Az ötven óra szolgálati tevékenység magába foglalja a felkészítő és feldolgozó órákat is, így az iskolai közösségi szolgálattal kapcsolatos attitűdök kapcsán fontos feltárni az ezekre vonatkozó tapasztalatokat is. A felkészítő és feldolgozó foglalkozások megtartása az iskolai közösségi koordinátor, mentortanár feladata, azonban gyakran az osztályfőnökök töltik be ezt a szerepet.

A vizsgálat eredményei szerint a diákok több mint fele több helyen teljesítette a szolgálatot, melyből arra következtethetünk, hogy a fiatalok igyekeztek változatos tevékenységeket végezni a szolgálat során. Megfigyeltük, hogy azok a tanulók, akiknek volt felkészítő órájuk, nagyobb arányban végezték változatos helyszíneken a szolgálatot (60 százalék), mint azok, akiknek nem volt iskolai felkészítés ( 55 százalék). Ezeknek az óráknak az egyik kiemelt szerepe az, hogy felkeltse a fiatalok érdeklődését a közösségi szolgálat iránt, segítse a személyiségükhöz illő, érdeklődésüknek megfelelő fogadószervezet kiválasztását. Az 
eredmények mégis azt mutatják, hogy az iskolai közösségi szolgálat hatékonyságában kulcsszerepet játszó órák gyakran elmaradnak, a tanulók kevesebb, mint fele (45 százalék) mondta azt, hogy volt felkészítő órája a közösségi szolgálatot megelőzően. Ebből arra következtethetünk, hogy a diákok igényeinek felmérésére (azaz, hogy hol szeretnék tölteni az 50 órát) csak kevés helyen került sor. A válaszok alapján azt láthatjuk, hogy mindössze a tanulók harmadának hozta meg a felkészítés a kedvét a szolgálathoz. Ez alacsony arány, tekintettel arra, hogy a felkészítő óráknak kiemelt szerepük van a szolgálat megítélését illetően. A felkészítés lehetőséget nyújt arra is, hogy tudatosítsák a diákokban az iskolai közösségi szolgálat céljait így, ha ezek a célok nincsenek letisztázva, maga a szolgálat is értelmét vesztheti.

A felkészítő órák mellett fontos szerep jut az iskolai közösségi szolgálatot koordináló pedagógusoknak is, akik legtöbbször a fogadószervezetekkel való kapcsolattartásért felelősek, valamint azért, hogy tájékoztassák a tanulókat az aktuális szolgálati tevékenységekről, és segítsék az adminisztratív teendőket. Vizsgálatunkban a tanulók 31\%-a állította azt, hogy volt olyan tanár az iskolában, akivel konzultálhatott, és akihez szükség esetén segítségért fordulhatott az iskolai közösségi szolgálati tevékenységével kapcsolatban. Úgy túnik tehát, hogy a tanulók több mint kétharmada magára marad az iskolai közösségi szolgálat teljesítésének feladatával és esetleges problémáival.

Ezek az eredmények arra engednek következtetni, hogy gyakran az iskolák felkészületlensége alapjaiban járul hozzá az iskolai közösségi szolgálattal kapcsolatos negatívabb attitûdök és az alulmotiváltság megteremtéséhez. Ha a kezdeti bizonytalanságokat, negatívabb attitúdöket nem követik pozitív tapasztalatok és élmények az iskolai közösségi szolgálattal kapcsolatban, akkor gyakran teherként, később negatív érzésként marad meg az ötven óra emléke.

Vizsgálatunkban egy hét elemből álló kérdésblokk segítségével megvizsgálatuk, hogy milyen tanulói csoportok rajzolódnak ki az attitűdök mentén. Öt tanulói csoport jött létre, melyek a következők:

- Pozitívak: Az ebbe a csoportba tartozó tanulóknak sikerült érdeklődésüknek megfelelő helyet találni, ahol hasznos, érdekes tevékenységeket végeztek; és szerették a szolgálatot. Az ide tartozó tanulók a megkérdezett diákok 24 százalékát tették ki. 
- Időhiányos pozitívak: A tanulók a közösségi szolgálatot pozitívan értékelték, alapvetően érdekesnek, hasznosnak találták; és szerették a tevékenységet, azonban úgy vélik, hogy sok időt vont el tőlük. Ez a csoport a tanulók 17 százalékát jelentette.

- Közömbösek: Azok a tanulók, akiknek nem sikerült olyan fogadóintézményhez menni, ahova szerettek volna, és nem is szerették meg az ott végzett tevékenységet. Emellett pozitívan értékelték a szolgálatot; érdekesnek találták, úgy érezték hasznos tevékenységet végeztek; és nem éltek meg teherként, időpazarlásként. Összességében megszerették a szolgálatot, de nem olyan mértékben, mint a pozitív vagy az időhiányos pozitív csoportok tagjai. A tanulók 24 százaléka tartozott ebbe a csoportba.

- Kritikusok: Azok a tanulók kerültek ebbe a csoportba, akiknek sikerült olyan fogadóintézményt találni, amelyet szerettek volna, és ott érdemleges és hasznos munkát is végeztek. Ugyanakkor tehernek érezték azt, ami sok időt von el tőlük. Ők nem szerették meg a végzett tevékenységet, nem találták érdekesnek, és összességében sem szerették a szolgálatot. Ez a csoport a tanulók 19 százaléka.

- Negatívak: Ezeknek a diákoknak már az érdeklődésüknek megfelelő területet sem sikerült kiválasztaniuk. A végzett tevékenység során sem sikerült megszeretni a területet, sem érdekesnek, sem hasznosnak nem tartották; és a végzett tevékenységet sem szerették meg. Úgy vélik a közösségi szolgálat teher volt számukra, és az 50 óra sok időt vont el a szabadidejükből. Összességében nem szerették meg a közösségi szolgálatot. Ebbe a csoportba tartozik a tanulók legkisebb hányada, mindössze 15 százalék.

\section{A társadalomstatisztikai jellemzők hatása}

Kíváncsiak voltunk, hogy milyen társadalomstatisztikai jellemzőkkel rajzolhatók körül a szolgálat iránt pozitívabb attitűdökkel rendelkező (pozitív és időhiányos pozitív csoportba tartozó) tanulók. A logisztikus regressziós eredmények azt mutatják, hogy a lányok, az alacsonyabb önkéntességi rátával rendelkező megyében élők; a kisebb, jellemzően faluban lakók; a technikumba járók és gyakrabban imádkozók pozitívabb attitűdökről számoltak be.

Ugyanakkor nem találtunk szignifikáns összefüggést a társadalmi háttér és az attitűdök között, amiből arra következtethetünk, hogy nem befolyásolja a társadalmi háttér a szolgálat iránti attitűdöket. Azaz, nem jelenthető ki, hogy a kedvezőbb gazdasági, kulturális háttérrel rendelkező tanulók és a jobb tanulmányi eredményűek pozitívabb attitűdöket társítottak volna a szolgálathoz, mint a kedvezőtlenebb gazdasági és kulturális tőkével rendelkezők. Ez 
pozitív eredmény, hiszen kirajzolódik, hogy az iskolai közösségi szolgálat a hátrányosabb helyzetúek körében is hatékony és hasznos eszköz lehet a társadalmi részvétel növelésére, az önkéntességbe való bevonódásba.

\section{(Szakmai) kapcsolatok kialakítása}

Vizsgáltuk továbbá, hogy a társadalmi háttértényezőkön kívül milyen más tényezők befolyásolhatják a szolgálat megítélését. Azt láthattuk, hogy a pozitívabb attitűdöket erősítheti az, ha a tanulók egy helyen végzik a szolgálatot. Ennek valószínűsíthető oka, hogy több idejük jut a fogadószervezet megismerésére, az alkalmazottakkal és a munkatársakkal való pozitív kapcsolatok kialakítására. Úgy tûnik, hogy a személyes kapcsolatok és az, ha hosszabb ideig egy helyen végzi a szolgálatot a tanuló, meghatározóbb a szolgálattal kapcsolatos pozitívabb attitűdök kapcsán. A pozitív attitűd elérését segíti még az, ha a tanuló a szakirányát össze tudja illeszteni a közösségi szolgálattal. Ez segítheti a pályaszocializációt, azaz a szakmai kapcsolatok kiépítését és a szakmai tapasztalatszerzést egyaránt.

\section{Az iskolai közösségi szolgálat képességfejlesztő hatása}

Kutatásunk célja volt az is, hogy monitorozzuk a tanulók önbevallásán alapuló képességfejlődésében bekövetkező változásokat. A középiskolások elsősorban a segítőkészségük fejlődéséről számoltak be, de úgy vélték, hogy fejlődött a munkával szembeni felelősségtudatuk és önállóságuk is. Eredményeink szerint a vizsgált képességek kétféle dimenzióba rendeződtek:

- a munkaerőpiaci (pl. csapatmunka, kritikus gondolkodás, segítőkészség, teherbírás, időkeretek betartása, konfliktusmegoldó készség, kreativitás) és

- az interkulturális (pl. más kultúrák megismerése, tolerancia velük szemben) képességek csoportjába.

A szolgálat iránti attitűdcsoportok szignifikáns összefüggést mutattak a képességcsoportokkal. Azok a tanulók, akik pozitívabban vélekedtek a szolgálatról, azaz a pozitív és időhiányos pozitív klasztercsoportokba tartoznak, szignifikánsan nagyobb képességfejlődésről számoltak be minden képesség esetén, mint a szolgálatról negatívabban vélekedők. Ez ugyancsak egy pozitív eredmény és láthatjuk, ha sikerül a tanulóknak pozitív attitúdöket kialakítani a szolgálatról - annak ellenére is, hogy olykor teherként tekintenek a szolgálatra, vagy épp 
szívesebben töltenék mással a szabadidejüket -, jobban tudatosul bennük az is, hogy milyen képességeik fejlődtek a szolgálat alatt.

Végezetül további eredményünk, hogy az iskolai közösségi szolgálat iránti pozitív attitűd nem csak a képességek fejlődése kapcsán kiemelten fontos, hanem eredményeink szerint kulcsszerepe van a társadalmi részvétel növelésében (önkéntesség, civil aktivitás, szociális érzékenység) és a pályaszocializációban (pályaorientáció segítése, munkahelyi beágyazódás).

\section{ÖSSZEGZÉS HELYETT - JAVASLATOK}

A következőkben néhány olyan javaslatot fogalmazunk meg, melyek megoldást nyújthatnak az iskolai közösségi szolgálat céljainak sikeresebb eléréséhez és a pozitívabb attitűdök kialakításához:

\section{Állampolgári szocializáció}

Úgy véljük, hogy az oktatásnak kiemelt szerepe van a fiatalok társadalmi részvételének növelésében, így az iskoláknak a pedagógiai programjaikban hangsúlyt kell fektetniük e prioritás megvalósítására. Az aktív állampolgári szerep elsajátítása szocializációs folyamat során megy végbe, az iskola pedig mint egyetemes közeg lehetőséget tud ehhez biztosítani. Ez elérhető akár az iskolai közösségi szolgálat tágabb tanulói rétegeinek bevonásával, mely az oktatási rendszer vertikális és horizontális képzési szintjeire való kiterjesztésével is végbemehet. Fontosnak tartjuk, hogy az aktív társadalmi magatartás elérése olyan szocializációs folyamat során menjen végbe, melyben az oktatási rendszer aktív szerephez jut a legalsóbb szinttől (óvodás kortól) a legfelsőbb szintig (felsőoktatás pl. közösségi szolgálati kurzusok meghirdetése).

\section{Kötelező versus nem kötelező dilemma}

A kutatásaink eredményei azt mutatják, hogy az iskolai közösségi szolgálattal kapcsolatos pozitív attitűd segíti a szolgálat céljainak megvalósulását. Ahhoz, hogy a pozitív attitűd minél több tanulóban kialakulhasson, az iskolai közösségi szolgálat átalakítására van szükség. Számos érv szól amellett, hogy az iskolai közösségi szolgálat megszüntetése lenne a megoldás, hiszen kötelező, a tanulók számára teher, ami a tanulástól vonja el az időt, nem beszélve arról, hogy igen gyakori a tanulók körében az 50 óra szolgálat elvégzése nélkül a „lepapírozás”. 
A kötelezőség melletti gyakori érv, hogy ha nem kötelezzük a fiataljainkat a szolgálat teljesítésére, a tanulók egy csekély száma venne részt önkéntes megmozdulásokban. $A$ kötelezőség által azok is bevonódhatnak az önkéntességbe (ha legfeljebb 50 óra erejéig is), akik alapvetően nem találkoznak környezetükben önkéntes lehetőségekkel.

\section{Hosszú távú pozitív hatások}

Felmerül a kérdés, hogy a felsoroltak ismeretében mégis miért szükséges kötelezni a tanulókat a szolgálat teljesítésére. A választ talán megadhatja az, hogy az iskolai közösségi szolgálat hosszú távú hatásai még nem ismertek. E hatás megmutatkozhat akár az önkéntesek számának emelkedésében, a civil aktivitás növekedésében vagy a fiatalok könnyebb munkaerőpiaci elhelyezkedésében. A szolgálatot végzett első évfolyamok jelenleg a felsőoktatási intézmények hallgatói vagy a munkaerőpiacra belépő fiatal munkavállalók. Nagymintás felmérés nem készült arról, hogy a középiskola befejezését követően milyen hosszú távú hatását érzékelik a tanulók a közösségi szolgálatnak.

\section{Választható szervezetek sokszínüsége}

A kötelezőség érzése csökkenthető a szabad választás elvének fenntartásával, miszerint a tanulóknak lehetőséget kell nyújtani ahhoz, hogy minél színesebb fogadószervezeti kínálatból választhassanak fogadószervezeteket, így az iskolákat ösztönözni kell arra, hogy minél több állami, egyházi és civil szervezettel lépjenek kapcsolatba. Az eredményeink azt mutatják, ha a tanulók nem tudnak olyan területet választani, amely érdeklődésüknek megfelelő, az már az 50 óra megkezdése előtt hozzájárul a negatív attitűdök kialakításához. Ha a tanulók olyan helyen végzik a szolgálatot, ami érdeklődési területüknek megfelelő, sokkal inkább képesek bevonódni a végzett tevékenységbe, és hatékonyabban jöhet létre az affektív és a tapasztalati tanulás.

\section{Koordinátorok szakmai felkészítése}

A szolgálat iránti pozitívabb attitűdök kialakításában kiemelt szerepe van a felkészítő és a feldolgozó óráknak, így a jövőben fontos lenne azokat szakmai felkészítésen átesett pedagógusoknak végezniük. Meglátásunk szerint nagyobb hangsúlyt kellene fektetni a felkészítő és feldolgozó órák megszervezésére, a koordináló pedagógusok felkészítésére (pl. a tanárképzésben, pedagógusképzésben szakirányi modulok indítása) és támogatására (pénzbeli vagy természetbeni támogatás pl.: órakedvezmény). Nemcsak a pedagógusok, de a 
fogadószervezetek koordinátorainak felkészítése is elengedhetetlen, hiszen, ha a szervezeti oldal nem képes a fiatalok számára izgalmas, kihívást jelentő szolgálati tevékenységet kínálni, gyökereiben hozzájárul a negatív tapasztalatok, attitűdök kialakításához.

\section{Hálózatosodás}

Fontos lenne a közösségi szolgálat aktorai körében egy jól múködő hálózat kiépítése, ahol egymás között megoszthatják a szolgálattal kapcsolatos feladatokat, információkat, és ahol segítségért tudnak fordulni egymáshoz, hiszen az minden érintett számára könnyebbséget jelentene. Javasoljuk a jövőben olyan koordinációs irodák (pl. iksz pontok) kialakítását, ahol felkészült szakemberek nyújthatnak segítséget a pedagógusoknak, a fogadószervezetek alkalmazottainak és a diákoknak egyaránt. Ezeken a koordinációs pontokon lehetőség nyílna a pedagógusok és a fogadószervezetek koordinátorai számára a képzések megszervezésére, jó gyakorlatok bemutatására, új módszerek megismertetésére, és segítséget kaphatnának az adminisztratív feladatok ellátásában is. Ezeknek az irodáknak a feladata lehetne a közösségi szolgálat teljesítésének szabályos kontrollja is, melynek hatására csökkenteni lehetne az 50 óra elvégzése nélküli leigazoltatások számát. Az itt dolgozó szakemberek továbbá felügyelnék azt, hogy a fogadószervezeteknél megfelelő bánásmódban részesüljenek a diákok, és valóban hasznos szolgálatot végezzenek. A koordinációs iroda akár terepet nyújthatna a szakszerü felkészítő és feldolgozó órák megszervezésének, és itt a fiatalok helyi szinten értesülhetnének az aktuális szolgálati tevékenységekről.

\section{Koncentrált felkészítés}

A felkészítő foglalkozásoknak még nagyobb hangsúlyt kell fektetniük a szociális érzékenyítésre, a feldolgozó óráknak pedig a reflexiók megvitatására. A különböző tanulási modellek (tapasztalati, közösségi, transzformális, affektív) rávilágítanak arra, hogy gyakran a megélt tapasztalatok prezentálása, a megfigyelések és a reflexiók számbavétele hozzásegíti a fiatalt ahhoz, hogy még inkább realizálódjanak és fontossá váljanak az egyes társadalmi problémák, önvizsgálatra késztetheti, melynek hatása cselekvésre invitálhatja az egyént. A felkészítő órákon tehát aktív szerepet kell vállalnia a fogadószervezetek koordinátorainak, ahol bemutathatják az intézményeiket, ismertethetik a végezhető tevékenységeket, továbbá szociálisan érzékenyíthetik a fiatalokat. Fontos ez azért is, hogy amikor a tanulók belépnek az intézménybe, gátlások nélkül, kellő felkészültséggel és ismerettel tudják szolgálatukat végezni. 
A kutatásaink szerint a tanulók többsége kifogásolja a magas szolgálati óraszámot. Szükséges lenne az iskolai közösségi szolgálatra való szocializációs folyamat során fokozatosan növelni az óraszámot, tehát az általános iskola alsóbb évfolyamain kisebb óraszámban, míg középiskolában nagyobb óraszámban meghatározni a szolgálati időt.

\section{Pályaorientáció segítése}

A technikumokba járó tanulók esetén megfigyelhettük, hogy a tanulók többsége törekszik arra, hogy olyan helyen végezze a szolgálatot, ami a szakmaterületének megfelelő. Fontos lenne a jövőben a szakképző iskolába járó diákok számára is bevezetni a szolgálatot, mivel segítheti a munkaerőpiaci szocializációt, mert a tanulók mintegy kiterjesztett szakmai gyakorlatként is tekinthetnének a szolgálatra, ahol szakmai tudást, tapasztalatot és kapcsolatokat szerezhetnek. Mindez támogathatja a tanulmányok befejezését követő könnyebb elhelyezkedést. További eredményünk, hogy az iskolai közösségi szolgálatnak társadalmi kiegyenlítő szerepe van, ezért javasoljuk a közösségi szolgálat kiterjesztését a szakképző iskolába járó jellemzően hátrányosabb helyzetű (alacsonyabb kulturális és társadalmi tőkével rendelkező) tanulók számára is. Az aktív állampolgári szerep kialakítása nem köthető iskolai fokozathoz.

\section{Módszertani fejlesztés}

Az iskolai közösségi szolgálat módszertana jelenleg jelentősen eltér a service-learning jellegű programok módszertanától. A szolgálat céljainak sikeresebb elérése érdekében szükséges lenne adaptálni a service learning módszertanát. A tantervbe önálló tananyagként megjelenő projektszerű közösségi szolgálat kialakítása az iskola részéről nagyobb szervezést igényel, hiszen a koordinátornak több projektet kell egyszerre szerveznie és fenntartania, de ugyanakkor hozzájárulnak ahhoz, hogy a felkészítések és a tapasztalatok feldolgozása sokkal célirányosabbak, ezáltal hatékonyabbak is legyenek. A közösségi szolgálat tantervbe való illesztésével több pedagógus (esetleg osztályfőnök) vonható be, akik felkészítő képzést követően maguk szervezhetik osztályaiknak a szolgálati projektet. Ha mindez az osztályfőnök feladatát képezné, sokkal célirányosabb, a tanulók érdeklődésének megfelelő projekteket tervezhetnének meg. A szolgálati sokszínúség biztosítható lenne úgy, ha félévente újabb társadalmi problémára koncentrálnának a projektek során, és újabb helyi szervezettel működnének együtt közösen. A szolgálat tantervbe illesztését megkönnyítheti a jelenleg is 
alap- és középfokú oktatás kerettantervének részét képező állampolgári ismeretek tantárgy átalakítása, abba való integrálása. Bár a szolgálat teljesítésének kötelezősége fennállna, mégsem a tanulók szabadidejéből vonná el az időt, ami növelhetné a lelkesedést. A korábbi kutatásaink azt mutatják, hogy azok a tanulók, akik osztálytársaikkal közösen vettek részt szolgálati tevékenységben, sokkal pozitívabb tapasztalatokkal rendelkeztek. A közösségépítés a projektszerű, tananyagba épített service learning jellegú szolgálati tevékenység közvetlen hatása is lehet.

A fentiek alapján látható, hogy az iskolai közösségi szolgálat átalakítása számtalan lehetőséget rejt. A felsorolt javaslatok mindössze néhány intézkedést tartalmaztak, mellyel igyekeztünk rávilágítani arra, hogy milyen színtereken és hogyan lenne érdemes beavatkozni a pozitívabb iskolai közösségi szolgálati élmény elérése érdekében.

\section{IRODALOM}

Baltes, Anna Maria - Seifert, Anne (2010): Germany: Service learning in its infancy. Phi Delta Kappa, 91(5), pp. 33-34. DOI: https://doi.org/10.1177/003172171009100509

Bekkers, René (2009): A new national service learning program in the Netherlands Preliminary Evidence. Forum 21. European Journal on Child and Youth Research, 3., pp. 62-68.

Bilik János (2013): Az 500 órás közösségi szolgálat: szociális tanulási projekt a Prohászka Ottokár Katolikus Gimnáziumban.

http://kozossegi.ofi.hu/Contents/DownloadFile?url=\%2FUploads\%2FDocuments\%2F3b5ad092-

2d8d-4437-8954-85300f986a11.pdf\&fileName=Bilik\%20J.\%20Szakdolgozat.pdf. Letöltve: 2018.06.26. Bodó Márton (2015a): Az iskolai közösségi szolgálat és a nemzetközi gyakorlat. In: Bodó Márton (szerk.): Az Iskolai Közösségi Szolgálat bevezetésének tapasztalatai 2015. Budapest, Oktatáskutató és Fejlesztő Intézet, pp. 9-37.

Bodó Márton (2015b): IKSZ Kutatások, Tapasztalatok. https://docplayer.hu/8614354-Iksz-kutatasoktapasztalatok.html Letöltve: 2021.03.10.

Bodó Márton (2016): A pedagógusszerep és az Iskolai Közösségi Szolgálat. Kapocs, 15(69) pp. 3-14.

Clifford, Joan (2017): Talking About Service-Learning: Product or Process? Reciprocity or Solidarity? Journal of Higher Education Outreach and Engagement, 21(4), pp. 1-13. ISSN: 1534-6104

Dokter, Betsy (2011): Civic internships for secondary school students and Fotorally: an opportunity to develop European citizenship.

http://ims.mii.lt/ims/konferenciju_medziaga/IFIP_2011/text/short\%20papers\%20in\%20pdf/doktor.p df Letöltve: 2018.06.26.

Domján Zsuzsanna (2014): Középiskolások közösségi szolgálatának bemutatása a zalaegerszegi Mindszenty József Általános Iskola Gimnázium és Kollégiumban.

http://kozossegi.ofi.hu/Contents/DownloadFile?url=\%2FUploads\%2FDocuments\%2F7a58835c-01324378-a84c-fbab32e7b957.pdf\&fileName=29_04_2014\%20pdf. Letöltve: 2018.06.21. 
Fényes Hajnalka - Markos Valéria (2016): Az intézményi környezet hatása az önkéntességre. In: Pusztai G. - Bocsi V. - Ceglédi T. (szerk.): A felsőoktatás (hozzáadott) értéke. Nagyvárad - Budapest, Partium - P.P.S.-Ú.M.K.

Furco, Andrew (1996): Service-learning: A Balanced Approach to Experiental Education. Expanding Boundaries: Service and learning. Corporation for National Service, Washington DC.

Jones, Lewellyn Angela - Kiser, Pamela M. (2014): Conceptualizing Criticality as a Guiding Principle for High Quality Academic Service Learning. International Journal of Teaching and Learning in Higher Education, 26(1) pp. 147-156. ISSN: 1812-9129

Markos Valéria (2016): Közösségi szolgálat vagy önkéntesség. Educatio, 25(3) pp. 444-450.

Markos Valéria (2018): A fogadószervezetek koordinátorainak tapasztalatai az iskolai közösségi szolgálatról. In. Iskolakultúra, 28(3-4) pp.12-27.

Markos Valéria (2020): Úton a felelös állampolgári lét felé. Az iskolai közösségi szolgálat közvetlen és közvetett hatásai. Oktatáskutatók Könyvtára 10. Cherd-Hungary.

Velkey Balázs (2014): A középiskolai közösségi szolgálat tapasztalatai.

http://kozossegi.ofi.hu/Contents/DownloadFile?url=\%2FUploads\%2FDocuments\%2F5b8ce5d4-4b6548d1-9ab5-ce5e01c22f23.pdf\&fileName=Szakdolgozat\%20-vezet\%C5\%91k\%C3\%A9pz\%C5\%91-

Velkey\%20Bal\%C3\%A1zs-2014.pdf Letöltve: 2018.06.08

Vonk, Adriaan (2011): Aprendizaje de Servicio. Barcelona.

http://www.aprenentatgeservei.org/intra/aps/documents/presentacio_Adriaan_Vonk.pdf Letöltve: 2018.06.28.

Zentner, Sandra (2011): "Lernen durch Engagement" - Service-learning in German schools. A promising way to get youth involved - in active learning and, in civic engagement. Publication of the network "Lernen durch Engagement ". Weinheim: Freudenberg Foundation, 17. 